\title{
Don't squander precious time on genes
}

Thl: House of Commons Select Committee on Science and rechnology is one of Britain's more valuable Parliamentary institutions. In the past it has held a number of important and useful inquiries--into Lord Rothschild's proposals for reorganising research council funding. for example, and Britain's choice of nuclear reactors. Even if the conclusions of such inquiries have been open to criticism, they have often thrown much-needed light on some of the murkier corners of government decision-making.

It is, however, difficult to be entirely enthusiastic about the select committee's decision last week to establish a subcommittee on genetic engineering-which presumably means the implications of current research using recombinant DNA techniques. Not that the subject lacks widespread public concern (perhaps more so in the United States than in Britain), nor that it is one on which politicians, in whose lap some of the important decisions may ultimately fall, are well informed. But the timing is wrong.

It is now over three years since the moratorium on recombinant DNA was announced by a group of scientists in the US, and in that time much has happened. Every country which carries out such experiments has now developed some form of control mechanism (some, admittedly, more effective than others). And in the process, the issues raised by the experiments have been subject to exhaustive scrutiny and debate. As a result, there now seems to be a general feeling that initial reactions may have been too strong. This cooling-off has undoubtedly been partly due to the successful lobbying of those with scientific and other interests in the continuation of such experiments. But there is also a general feeling among many scientists that the dangers, although real and potentially extremely hazardous, have been overplayed.

In these circumstances, it is difficult to see what the select committee will be able to achieve. The area is not one which, like some previous issues, can claim to have suffered from lack of public debate. This is not to claim any particular immunity for decision-making processes within the scientific community. But although such an inquiry would have been useful two years ago, there seem to be more pressing and potentially significant issues at the present time. Examples might be the future needs for scientific manpower, or the definition and management of technological risk in general (which might, indeed, still be embraced by expanding the terms of reference of the new subcommittee). The select committee's time is a precious commodity; it would be a pity if it was squandered on re-opening the scars of previous battles.

\section{China's path ahead}

W: bring together in this issue of Nature a number of reports on recent developments in science within the People's Republic of C'hina, together with a note on the Peking/Taipei conflict. which is at present reverberating within the international unions. Some of the barriers between the People's Republic and the rest of the world were lifted five years ago. Yet it is still possible for the Chinese to spring surprises on us-with their great wealth of data. their respect for the role of the amateur in some scientific fields, and most recently with the obvious signs of a profound interest in re-establishing science and technology as a thoroughly professional pursuit. This latter trend can be seen not only in the way that university and institutional research is being revived for the purpose of obtaining economic henefits for the nation, but also in the way that certain selected branches of science with less obvious practical benefits are to be stimulated. The all-China meeting in the Spring to discuss national policies on science and technology is bound to be a fascinating occasion.

The path ahead for China is by no means simple, however. Renewing a respect for pure research, for theoretical understanding as well as practical achievement, even for an elitist rather than populist approach, will not be easy after half a generation in which many of the invisible threads of tradition in the scientific method may have been damaged. But perhaps an even more difficult task will be for the Chinese to hold fast to those elements of people's science which have proved so successful in recent years, most notably the accurate reporting of natural phenomena whether they be connected with health, agriculture or stirrings within the earth. For in some instances this mobilisation of the masses has had major successes-the use of amateur scientists in earthquake prediction, for instance, with many quakes now successfully predicted, puts the Chinese well ahead of the rest of the world.

How maintain a broad public involvement in science and technology while giving the experts their head? And how cope with an almost inevitable demand from a newly-arisen intelligentsia for a greater extension of human rights and liberties? These are among the questions that China must confront in the next decade with its new mood of enthusiasm for science. 